\title{
PENANAMAN NILAI ANTIKOROUPSI BAGI MAHASISWA FIS UNNES MELALUI MATA KULIAH PENDIDIKAN ANTI KORUPSI
}

\author{
Natal Kristiono
}

Universitas Negeri Semarang

Email: natalkristiono@mail.unnes.ac.id

\section{Info Artikel}

\section{Sejarah Artikel:}

Diterima 11 Oktober 2018

Direvisi 31 Oktober 2018

Disetujui 30 November 2018

Keywords:

Value, Education, Anti

Corruption

\section{Abstract}

The purpose of this study was to determine the success of the implementation of AntiCorruption Education lectures. One indicator of success, namely after participating in Anti-Corruption education students can afford anti-corruption education, among others, to know the dangers of corruption. can understand anti-corruption values. character change. The factors that support the success of anti-corruption education are self-awareness factors, media and learning resources and the selection of appropriate strategies. Factors that hinder the success of anti-corruption education are environmental factors and mistakes in choosing the media and learning strategies.

\begin{abstract}
Abstrak
Tujuan penelitian ini adalah untuk mengetahui keberhasilan pelaksanaan perkuliahan Pendidikan Anti Korupsi. Metode penelitian yang di gunakan adalah menggunakan angket/kuesioner. Salah satu indikator keberhasilan, yaitu setelah mengikuti pendidikan Antikorupsi siswa mampu pendidikan antikorupsi antara lain mengetahui bahaya dari tindak pidana korupsi. dapat mengerti nilai-nilai antikorupsi. perubahan karakter. Faktor penunjung keberhasilan pendidikan antikorupsi yaitu Faktor kesadaran dalam diri sendiri, media dan sumber belajar dan pemilihan strategi yang tepat. Faktor yang menghambat kebarhasilan pendidikan antikorupsi yaitu faktor lingkungan dan kesalahan dalam memilih media dan strategi belajar
\end{abstract}


Kristiono, Natal

PENANAMAN NILAI ANTIKOROUPSI BAGI MAHASISWA FIS UNNES MELALUI ...

REFLEKSI EDUKATIKA : Jurnal Ilmiah Kependidikan, Nomor 9, Volume 1, Desember 2018, hlm 40-45

\section{PENDAHULUAN}

Untuk memberantas korupsi di Indonesia tidak cukup hanya dengan melakukan tindakan preventatif atau pencegahan. Salah satu upaya yang dapat dilakukan melalui tindakan preventatif ini adalah dengan menumbuhkan kepedulian untuk melawan berbagai tindakan korupsi, dan sekaligus juga mendidik generasi muda dengan menanamkan nilai-nilai etika dan moral yang diperlukan dalam kehidupan bermasyarakat. Banyak hal yang di lakukan, misalnya melalui kampanye publik, maupun melalui penanaman nilai-nilai moral dan etika yang dapat di masukan dalam pendidikan seperti di SD, SMP, SMA maupun Perguruan Tinggi. Dengan upaya ini diharapkan mereka dapat tumbuh menjadi generasi yang bersih dan anti korupsi sekaligus menjadi contoh generasi sesudahnya dan sebelumnya. Kesadarn dan kepedulian masyarakat perlu di tumbuhkan melalui berbagai cara, antara lain dengan mencanangkan "gerakan anti korupsi", yang menandai komitmen berbagai elemen masyarakat dalam memberantas korupsi.

Selama ini menumbuhkan generasi anti korupsi yang bersih dan anti kosupsi ini telah dilakukan melalui kerjasama antara Komisi Pemberantasan Korupsi (KPK) selaku lembaga pemerintah, Kemendiknas dan sekolah sebagai pelaksanaan pasal 13 UU. No. 30 Tahun 2002 tentang Pemberantasan Tindak Pidana Korupsi, yaitu bahwa KPK menyelenggarakan program pendidikan anti korupsi bekerjasama dengan Depdiknas pada setiap jenjang pendidikan melalui sosialisasi, komunikasi dam pemdidikan. Tujuan pembelajaran pendidikan antikorupsi adalah, 1) pada saat terjun ke masyarakat siswa telah mendapat bekal uang cukup untuk dapat memahami etika di setiap level "social leaders" yang di jalaninnya, 2) memahami secara komprehensif pentingnya etika baik di sektor publik maupun di sektor privat, 3) mengenali dan memahami dampak buruk korupsi terhadap kepercayaan masyarakat dan persaingan di dunia Internasional, dan 4) memiliki keberanian dan kebijaksanaaan untuk memberantas korupsi (Sjahrudin 2006).

Sebuah penelitian dampak pendidikan anti korupsi yang dilakukan di salah satu sekolah di kota semarang di temukan hal-hal sebagai berikut: Pertama, secara umum siswa ini mempunyai kesadaran (awarenes) yang tinggi atas kasus korupsi yang telah peroleh dari beberapa media cetak maupun elektronik. Kedua, pengetahuan (knowledge) tentang korupsi.
Pengetahuan mereka hanya terbatas pada kasus ataupun tempat (locus) terjadinya korupsi namun mereka tidak memiliki pemahaman yang tepat menganai definisi dan aturan hukum tentang korupsi. Ketiga, sikap (attitude). Umumnya responden menunjukan sikap tidak setuju terhadap terhadap tindak pidana korupsi yang banyak terjadi. Keempat, tingkah laku (behavior). Responden yang terdiri dari siswasiswa menengah ini cenderung memilih bersikap tidak melakukan apa-apa atas fenomena korupsi yang terjadi.

Terdapat beberapa dampak atau akibat yang diharapkan dari pelaksanaan pendidikan anti korupsi di sekolah menengah di kota semarang, yaitu 1) siswa sekolah menengah di kota semarang akan memiliki tanggung jawab manajerial, dan tanggung jawab publik, 2) siswasiswa sekolah menengah di kota semarang akan memiliki pemahaman etika di setiap level "sosial leadres" yang dijalaninnya, 3) siswa-siswa sekolah menengah di kota semarang akan memiliki pemahaman secara komprehensif etika di sektor publik dan privat, 4) siswa-siswa sekolah menengah di kota semarang akan mengenali dan memahami dampak korupsi terhadap kepercayaan masyarakat dan persaingan di dunia Internasional. 5) siswa-siswa sekolah menengah di Kota Semarang akan memiliki keberanian dan kebijaksanaan untuk memberantas korupsi, dan 6) siswa-siswa sekolah menengah di kota semarang kelak menjadi generasi yang bersih, transparan, profesional.

Faktor-faktor yang menghambat pelaksanaan Pendidikan Antikorupsi di sekolah Menengah kota semarang, yaitu faktor paradigama pendidikan antikorupsi. Paradigama yang di gunakan adalah paradigma pendidikan lama yang bersifat formalitas dengan mengabaikan sikap, moralitas, kecerdasan emosional dan spiritual, bukan paradigma pendidikan kritis, yakni pendidikan yang dikaitkan dengan kesadaran yakni perilaku Individu dalam memandang dan mengonseptualisasikan dunianya sebagai wawasan yang mereka miliki.

Faktor diri pribadi siswa. Kurangnya pemahaman bahwa kebiasaan yang dianggap wajar dan lumrah oleh siswa-siswa sekolah menengah di kota semarang, antara lain sikap suka menerabas (cutting-corner attitude), tidak disiplin dan menyontek merupakan bagian dari korupsi. Kuranganya sosialisasi yang dilakukan oleh Komisi Pemberantasan Korupsi (KPK) di 
Kristiono, Natal

PENANAMAN NILAI ANTIKOROUPSI BAGI MAHASISWA FIS UNNES MELALUI ... REFLEKSI EDUKATIKA : Jurnal Ilmiah Kependidikan, Nomor 9, Volume 1, Desember 2018, hlm 40-45

sekolah-sekolah menengah di kota semarang sehingga pendidikan antikorupsi belum banyak dipahami oleh guru dan siswa sekolah menengah di Kota Semarang. Keterbatasan modul pendidikan anti korupsi baik dari segi kualitas dan kuantitas yang dapat digunakan untuk pembelajaran pendidikan antikorupsi. Modul ini harus di sesuakan dengan situasi dan kondisi pada masing-masing jenjang pendidikan.

Berdasarkan substansi tersebut, maka penulis memfokuskan pada permasalahan mengenai nilai nilai anti korupsi yang diajarkan, dampak setelah mengikuti perkuliahan Pendidikan Anti korupsi serta faktor yang mendorong dan menghambat pelaksanaan penanaman pendidikan antikorupsi. Tujuan dari penelitian ini diharpakan mampu memberikan konstribusi positif terkait pembelajaran Pendidikan Anti Korupsi.

\section{METODE PENELITIAN}

Penelitian ini menggunakan penelitian deskript kualitatif. Adapun dalam menggali data penelitian, peneliti menggunakan menggunakan angket/kuesioner. Menurut Nazir (1998), Kuesioner atau daftar pertanyaan adalah sebuah set pertanyaan yang secara logis berhubungan dengan masalah penelitian, dan tiap pertanyaan merupakan jawaban-jawaban yang memounyai makna dalam menguji hipotesis. Daftar pertanyaan tersebut dibuat cukup terperinci dan lengkap. Arikunto (2000) mengatakan bahwa kuisoner/angket adalah daftar pertanyaan yang diberikan kepada orang lain yang bersedia memberikan respon sesuai dengan permintaan pengguna.

Dengan demikian angket/kuisoner adalah daftar pertanyaan yang disiapkan oleh peneliti dimana tiap pertanyaan berkaitan dengan masalah penelitian. Angket tersebut diberikan kepada responden dalam hal ini adalah mahasiswa PPKn FIS Unnes yang menempuh mata kuliah Pendidikan Antikorupsi untuk dimintakan jawaban. Angket merupakan daftar pertanyaan yang diberikan kepada orang lain dengan maksud agar orang yang diberikan tersebut bersedia memberikan respon sesuai dengan permintaan pengguna.

Angket dalam suatu penelitian terdiri atas 1) Angket terbuka yaitu angket yang di sajikan dalam bentuk sedemikian rupa sehingga responden dapat memberikan isian sesuai dengan kehendak dan keadaannya; 2) Angket tertutup yaitu angket yang disajikan dalam bentuk sedemikian rupa sehingga responden tinggak memberikan centang (v) pada kolom atau tempat yang sesuai; 3) Angket campuran yaitu gabungan antara angket terbuka dan tertutup.

Pada penelitian ini yang di gunakan adalah angket terbuka. Dimana peneliti memberikan daftar pertanyaan yang harus di isi oleh responden. Pertanyaan yang di ajukan sesuai dengan apa yang menjadi permasalah dalam penelitian ini. Responden adalah mahasiswa yang mengambil pendidikan Antikorupsi, yakni mahasiswa PPKn angkatan 2016 Universitas Negeri semarang. Namun tidak semua mahasiswa PPKn angkatan 2016, hanya beberapa yang di jadikan pengambilan sempel observasi. Observasi dilakukan pada tanggal 1125 Mei 2018.

\section{HASIL DAN PEMBAHASAN \\ Nilai-nilai Pendidikan Antikorupsi}

Wibowo (2013:38) menyatakan bahwa pendidikan antikorupsi adalah usaha sadar dan terencana untuk mewujudkan proses dan belajar mengajar yang kritis terhadap nilai-nilai anti korupsi. Dalam proses tersebut, maka pendidikan antikorupsi bukan sekedar media bagi transfer pengalihan pengetahuan (kognitif), namun juga menekankan pada upaya pembentukan karakter (afektif), dan kesadaran moral dalam melakukan perlawanan (psikomotorik), terhadap penyimpangan perilaku korupsi. Dari pengertian tersebut dapat di simpulkan bahwa pendidikan antikorupsi adalah usaha sadar untuk memberikan pemahaman dan pencegahan terjadinya perbuatan korupsi yang dilakukan melalui pendidikan formal, pendidikan informal, dan pendidikan nonformal.

Dalam pendidikan antikorupsi diajarkan pula nilai-nilai antikorupsi, yaitu kejujuran, kepedulian, kemandirian, kedisiplinan, tanggung jawab, kerja keras, sederhana, keberanian, dan keadilan. Menurut Sugono (2008) kata jujur dapat di definisikan sebagai lurus hati, tidak berbohong, tidak curang. Jujur adalah salah satu sifat yang sangat penting bagi kehidupan mahasiswa, tanpa sifat jujur mahasiswa tidak akan dipercaya dalam kehidupan sosialnya.

Nilai kejujuran dalam kehidupan kampus yang diwarnai dengan budaya akademik sangat di perlukan. Nilai kejujuran ibaratnya seperti mata uang yang berlaku dimana-mana termasuk dalam kehidupan kampus. Jika mahasiswa terbukti melakukan tindakan yang tidak jujur, baik di lingkup akademik maupun sosial, maka selamanya orang lain akan selalu merasa ragu untuk mempercayai mahasiswa tersebut. Nilai 
Kristiono, Natal

PENANAMAN NILAI ANTIKOROUPSI BAGI MAHASISWA FIS UNNES MELALUI ... REFLEKSI EDUKATIKA : Jurnal Ilmiah Kependidikan, Nomor 9, Volume 1, Desember 2018, hlm 40-45

kepedulian sangat penting bagi seorang mahasiswa dalam kehidupan di kampus dan masyarakat. Sebagai calon pemimpin masa depan, seorang mahasiswa perlu memiliki rasa kepedulian terhadap lingkungannya. Baik di lingkungan kampus maupun lingkungan di luar kampus.

Upaya yang bisa dilakukan sebagai wujud kepedulian diantaranya adalah dengan menciptakan suasana kampus sebagai rumah kedua. Hal ini dimaksudkan agar kampus menjadi tempat untuk mahasiswa berkarya, baik kurikuler maupun ekstra-kurikuler tanpa adanya batasan ruang gerak. Upaya lain yang dapat dilakukan adalah memberikan kesempatan bagi mahasiswa untuk menggalang dana guna memberikan bantuan biaya pendidikan bagi mahasiswa yang membutuhkan. Adanya aksi tersebut maka interaksi mahasiswa satu dengan yang lain akan semakin erat. Tindakan lainnya adalah dengan memperluas akses mahasiswa kepada dosen di luar jam kuliah melalui pemanfaatan internet dan juga meningkatkan peran dosen sebagai fasilitator, dinamisator, dan motivator.

Kondisi mandiri bagi mahasiswa dapat diartikan sebagai proses mendewasakan diri yaitu dengan tidak bergantung pada orang lain untuk mengerjakan tugas dan tanggung jawabnya. Hal ini penting untuk masa depan dimana mahasiswa tersebut harus mengatur kehidupannya dan orang-orang yang berada di bawah tanggungjawabnya sebab sebab tidak mungkin orang yang tidak dapat mandiri (mengatur dirinya sendiri) akan mampu mengatur hidup orang lain. Karakter kemandirian tersebut mahasiswa dituntut untuk mengerjakan semua tanggungjawab dengan usahanya sendiri dan bukan orang lain (Supardi 2004).

Sugono (2008) menyatakan bahwa disiplin adalah ketaatan (kepatuhan) kepada peraturan. Dalam mengatur kehidupan kampus baik akademik maupun sosial mahasiswa perlu hidup disiplin. Manfaat hidup disiplin yaitu mahasiswa dapat mencapai tujuan hidupnya dengan waktu yang lebih efisien. Disiplin juga membuat orang lain percaya dalam mengelola suatu kepercayaan.

Sugono (2008) menyebut definisi tanggungjawab adalah keadaan wajib menanggung segala sesuatunya (kalau terjadi apap-apa boleh di tuntut, dipersalahkan dan di perkatalan). Mahasiswa yang memiliki rasa tanggungjawab akan memiliki kecenderungan menyelesaikan tugas lebih baik dibanfing mahasiswa yang tidak memiliki rasa tanggungjawab.

Bekerja keras didasari dengan adanya kemauan. Kata kemauan menimbulkan asosiasi dengan ketekadan, ketekunan, daya tahan, tujuan jelas, daya kerja, pendirian, pengendalian diri, keberanian, ketabahan, keteguhan, tenaga, kekuatan, laki-lakian dan pantang mundur. Bekerja keras merupakan hal yang penting guna tercapainya hasil sesuai dengan terget.

Gaya hidup sederhana sangat penting bagi mahasiswa, gaya hidup sederhana mahasiswa dibiasakan hidup tidak boros, hidup sesuai dengan kemampuannya dan dapat memenuhi kebutuhannya. Dalam menerapkan prinsip hidup sederhana, mahasiswa dibina untuk memproritaskan kebutuhan atas keinginannya. Membentuk sikap keberanian mahasiswa dituntut untuk tetap berpegang teguh pada tujuan. Mahasiswa memerlukan keberanian untuk mencapai kesuksesan. Mengembangkan sikap keberanian demi mempertahankan pendiriannya dan keyakinannya, mahasiswa harus mempertimbangkan berbagai masalah dengan sebaik-baiknya. Pengetahuan yang mendalam menimbulkan perasaan percaya kepada diri sendiri.

Berdasarkan arti katanya, adil adalah sama berat, tidak berat sebelah, tidak memihak. Bagi mahasiswa karakter adil ini perlu sekali dibina sejak masa perkuliahannya agar mahasiswa dapat belajar mempertimbangkan dan mengambil keputusan secara adi dan benar.

\section{Dampak setelah mengikuti Pendidikan Antikorupsi \\ Pendidikan Antikorupsi dimaksudkan} supaya setelah mengikuti pendidikan antikorupsi orang tersebut bisa lebih kritis terhadap korupsi. Dampak dari mahasiswa yang telah mengikuti pendidikan antikorupsi antara lain mengetahui bahaya dari tindak pidana korupsi. Bahaya tindak pidana korupsi antara lain dalam bidang ekonomi korupsi merusak perkembangan ekonomi suatu negara. Jika suatu aktivitas ekonomi dijalankan dengan unsur-unsur korupsi, maka pertumbuhan ekonomi yang diharapkan tidak akan tercapai. Menimbulkan efek pada kurangnya investasi dan kepercayaan. Hal ini dikarenakan para infestor menjadi ragu dan takut untuk mempercayakan modalnua untuk dikelola didaerah yang korup. Tentunya dengan tidak adanya investor maka perputaran ekonomi di suatu daerah menjadi lambat atau bahkan berhenti. Dibidang politik, kekuasaan yang di capai dengan korupsi akan 
Kristiono, Natal

PENANAMAN NILAI ANTIKOROUPSI BAGI MAHASISWA FIS UNNES MELALUI ...

REFLEKSI EDUKATIKA : Jurnal Ilmiah Kependidikan, Nomor 9, Volume 1, Desember 2018, hlm 40-45

menghasilkan pemerintahan yang tidak sehat. Pemerintah yang berkuasan cenderung menjadikan alat kuasanya sebagai bentuk meraup keuntungan sebesar-besarnya dari apa yang bisa didapatkannya dari tampuk kekuasaan dan lain lain.

Dampak dari pendidikan antikorupsi yang lain yaitu dapat mengerti nilai-nilai antikorupsi. Nilai-nilai antikorupsi antara lain Kejujuran, kepedulian, Kemandirian, kedisiplinan, Tanggungjawab, kerja keras, sederhana, keberanian, dan keadilan. Nilai-nilai tersebut diharapkan dapat di laksanakan setelah mengikuti pendidikan antikorupsi. Menjalankan nilai-nilai tersebut maka siswa/mahasiswa tidak akan melakukan tindak pidana korupsi di masa yang akan datang.

Dampak mengikuti pendidikan antikorupsi yaitu perubahan karakter. Perubahan karakter disini yaitu perubahan karakter yang lebih baik. Yang sebelumnya biasa melakukan tindakan-tindakan korupsi menjadi meninggalkan tindakan-tindakan tersebut. Sehinnga saat terjun didunia kerja orang tersebut tidak melukan tindak pidana korupsi.

\section{Faktor Penunjang dan Penghambat Pendidikan Antikorupsi \\ Pelaksanaan pendidikan Antikorupsi} terdapat hal-hal penunjang keberhasilan pelaksanaan pendidikan antikorupsi, yaitu kesadaran dalam diri sendiri. Pendidikan faktor kesadaran diri sangat diperlukan, hal ini dikarenakan kesadaran diri sendiri merupakan salah satu faktor penting dalam dunia pendidikan. Jika diri sudah sadar akan pentingnya pendidikan antikoruspi maka materi yang disampaikan akan mudah di terima. Namun sebaliknya, jika diri ini belumsadar akan pentingnya pendidikan antikorupsi maka materi yang akan di sampaikan tidak akan bisa diterima.

Faktor yang lain yaitu faktor media dan sumber belajar. Media sangat di perlukan dalam proses pembelajaran. Hal ini karena media dapat mengefektifkan proses pembelajaran. Adanya media, dosen akan lebih mudah dalam menyampaikan materi pembelajaran. Selain itu ada sumber belajar. Sumber belajar bisa berbentuk buku, guru, maupun sumber belajar elektronik. Sumber belajar juga salah satu faktor penunjang keberhasilan pendidikan Antikorupsi. Dengan adanya sumber belejar siswa/mahasiswa bisa belajar sendiri tanpa adanyaa himbauan dari guru.
Faktor penunjang keberhasilan yang lain yaitu pemilihan strategi pembelajaran. Pemeilihan strategi pembelajaran hendaknya di sesuaikan dengan materi yang akan di sampaikan. Selain itu strategi pembelajaran juga di sesuaikan dengan kondisi para siswa tersebut.

Ada faktor penunjang keberhasilan ada juga faktor penghambat keberhasilan pendidikan antikorupsi, antara lain faktor lingkungan. Faktor lingkungan mempunyai peran yang fital dalam membentul watak seseorang. Karane watak seseorang tergantung pula kondisi lingkungannya. Jika lingkungan kita sudah terbiasa melakukan korupsi maka pendidikan antikorupsi akan sulit.

Pemilihan media dan strategi pembelajaran yang kurang tepat. Ketepatan pemilihan media sangan penting bagi proses pembelajaran. Karena proses belajar akan efektif jika media dan strategi yang digunakan sesuai dengan materi yang di ajarkan. Jika salah dalam memilih media dan strategi maka pembelajaran akan membosankan dan siswa akan merasa jenuh sehingga tidak memperhatikan materi yang di sampaikan.

\section{SIMPULAN}

Berdasarkan hasil penelitian, maka dapat disimpulkan bahwa penanaman nilai antikorupsi melalui mata kuliah Pendidikan Antikorupsi efektif berhasil, hal ini ditunjukan dengan kegiatan sehari hari mahasiswa dalam kehidupan dikampus maupun diluar kampus. Hal ini bisa dilihat dari kemampuan mahasiswa mengenai bahaya korupsi, tidak melalukan kecurangan akademik, serta tidak terlambat dalam mengumpulkan tugas dari dosen.

Pendidikan Antikorupsi merupakan langkah awal untuk mencegah terjadinya korupsi di masa yang akan datang. Generasi muda penerus bangsa bisa lebih mengerti apa bahaya dari korupsi sehinnga tidak melakukan korupsi. Untuk itu pendidikan antikorupsi perlu di tingkatkan statusnya dari mata kuliah wajib fakultas menjadi mata kuliah umum yang beralku disemua program studi di universitas.

\section{DAFTAR PUSTAKA}

Astuti, Indri. 2017. Politik Hukum UndangUndang Tindak Pidana Korupsi. Forum Ilmu Sosial 41 (2). 
Kristiono, Natal

PENANAMAN NILAI ANTIKOROUPSI BAGI MAHASISWA FIS UNNES MELALUI ...

REFLEKSI EDUKATIKA : Jurnal Ilmiah Kependidikan, Nomor 9, Volume 1, Desember 2018, hlm 40-45

Bahri, Syamsul. 2008. Buku Panduan Guru Modul Pendidikan Anti Korupsi Tingkat SMP/MTS. Jakarta : KPK.

EY, Lestari dan Natal Kristiono. 2015. Implementasi Undang-undang Nomor 6 tahun 2014 Tentang Desa Terhadap Percepatan Pembangunan Masyarakat di Kecamatan Dawe Kabupaten Kudus. Journal Integralistik 26 (2), hlm. 100-114.

EY, Lestari. Peran Strategis Kearifan Lokal Dalam Pendidikan Karakter Melalui Pembelajaran Pendidikan Kewarganegaraan Di Era Disrupsi. Makalah Dalam Seminar Nasional Pendidikan Kewarganegaraan IV, 194-200.

Handoyo, Eko. 2015. Pendidikan Antikorupsi.Yogyakarta : Ombak.

Handoyo Eko, dan Susanti, Martien Herna. 2014. Dampak korupsi melalui pendidikan antikorupsi dalam membentuk generasi muda yang jujur dan berintegritas di SMA Semesta Kota Semarang. ABDIMAS 18 (1).

Kristin, Firosalia. 2018. Meta-Analisis Pengaruh Model Pembelajaran Role Playing Terhadap Hasil Belajar IPS. Refleksi Edukatika Jurnal Ilmiah Kependidikan 8 (2).

Kristiono, Natal. 2018. Pendidikan Anti Korupsi Pergulatan Antara Pemikiran dan Pendidikan. Semarang : CV Cipta Prima Nusantara

Kristiono, Natal. 2018. Model Pendidikan Antikorupsi Di Sekolah Sebagai Pembentukan Karakter Siswa ( dalam Pendidikan karakter, Masalah dan Solusinya). Semarang: Jurusan PKN Unnes.

Kristiono, Natal. 2017. Penguatan Ideologi Pancasila Di Kalangan Mahasiswa Universitas Negeri Semarang. Jurnal Harmony 2 (2), hlm. 193-204.

2018. Penanaman Karakter Anti Korupsi Melalui Mata Kuliah Pendidikan Anti Korupsi Bagi Mahasiswa Fakultas Ilmu Sosial Universitas Negeri Semarang. Jurnal Hibualamo 2 (2), hlm. 51-56.
Kristiono, Natal dan Indri Astuti. 2014. Politik Hukum Pemberantasan Korupsi. Jurnal Seminar Nasional Hukum Universitas Negeri Semarang 4 (03), hlm. 967-984.

Mahfud, Moh. 2014. Politik Hukum Di Indonesia. Jakarta : Rajawali Press.

Mas, Marwan. 2014. Pemberantasan Tindak Pidana Korupsi. Bogor: Ghalia Indonesia.

Muhammad, Reno. 2010. Save KPK Save Polri Save Indonesia. Jakarta : Mizan Publika.

Oktaviani, Ika dan Santoso. 2014. Penerapan Cooperative Learning Tipe Stad Dan Snowball Drilling Untuk Meningkatkan Keaktifan Dan Prestasi Belajar IPS. Refleksi Edukatika Jurnal Ilmiah Kependidikan 4(2).

Perdana, Novrian Satria. 2018. Implementasi Peranan Ekosistem Pendidikan Dalam Penguatan Pendidikan Karakter Peserta Didik. Refleksi Edukatika Jurnal Ilmiah Kependidikan 8 (2).

Saputra, Iyus Herdiana dan Nasrudin. 2015. Pengembangan model pendidikan Antikorupsi dalam pembelajaran Al-Islam dan kemuhamadiyahan di Universitas Muhamadiyah Purworejo. CAKRAWALA, X (1).

Soemardihardjo, Dyatmiko. 2012. Memberantas Korupsi di Indonesia. Yogyakarta: CV Solusi Distribusi.

Tim Penulis. 2016. Buku panduan Dosen Pembelajaran Pendidikan Anti Korupsi untuk Perguruan Tinggi. Jakarta : Biro Kerja Sama dan Komunikasi Publik, Kementrian Riset, Teknologi, dan Pendidikan Tinggi.

Yuntho, Emerson. 2011. Negeri di Kepung Koruptor. Malang: Instrans Publishing.

Zachrie, Ridwan dan Wijayanto. 2009. Korupsi Mengorupsi Indonesia Sebab, Akibat dan Prospek Pemberantasan. Jakarta: Gramedia Pustaka Utama. 